International Journal of Linguistics, Literature and Translation

ISSN: 2617-0299 (Online); ISSN: 2708-0099 (Print)

DOI: $10.32996 / \mathrm{ijllt}$

Journal Homepage: www.al-kindipublisher.com/index.php/ijltt

IJLLT

\title{
Portrayal of Instability and Vulnerability of Modern Life in the Selected Poems of Robert Frost and Mathew Arnold: A Comparative Study
}

\author{
Most. Mushfeka Zannat ${ }^{1} \square$ Chowdhury Adiba Zahin ${ }^{2}$ and Jannat -E- Hosne Ara ${ }^{3}$ \\ ${ }^{12}$ Department of English, Bangladesh Army University of Science and Technology Saidpur, Rangpur- 5310. \\ ${ }^{3}$ Department of English, Mawlana Bhashani Science and Technology University Santosh, Tangail- 1902.
}

$\square$ Corresponding Author: Most. Mushfeka Zannat, E-mail: mushfekazannat14@gmail.com

ARTICLE INFORMATION ABSTRACT

Received: 11 October 2021

Accepted: 17 November 2021

Published: 30 November 2021

DOI: 10.32996/ijllt.2021.4.11.21

\section{KEYWORDS}

Modernity, alienation, pessimism, isolation, doubtfulness, self-

centeredness
This paper attempts a comparative study in the presentation of vulnerability and instability evident in people's life due to modernity by Mathew Arnold, a Victorian poet, and Robert Frost, a Modern American poet. Investigating various features with crises existing in modern life is a major aim of this paper. Moreover, the comparative analysis seeks to identify the major similarities and differences in the portrayal of human nature based on modern features in the poetry of these two poets. Since this research is theoretical in nature, it depends primarily on reviewing already published works on the relevant topics. The presence of modern elements is very obvious in the writings of both the poets though they belong to two different periods. Their poetry reflects modern crisis and vulnerability like alienation, pessimism, doubtfulness, isolation, self -centeredness, and so on. Nature is also treated in a different way as well as the reality of modern life represented in a different light by the poets. Finally, this research focuses on bringing out the features of instability and vulnerability of modern life that are still mirrored in contemporary society.

\section{Introduction}

This paper investigates the evidence of modern life traced in the writings of two poets of two different eras, namely Mathew Arnold and Robert Frost and aims to make a comparative analysis of their poems. Mathew Arnold is the notable poet of the Victorian period, whereas Robert Frost is a modern poet. However, the poems of both of the poets have represented the instability of modern life and its far-reaching consequences. Frost's poetry portrays the degradation of values of modern life in symbolical and metaphysical terms and people's suffering from loneliness and frustration. Besides, his poems highlight the disillusionments of modern man and the problem prevailing in the modern world dominated by science and technology that is similar to the depiction of Mathew Arnold's poetry which has focused mainly on the loss of value and faith due to the advancement of technology during the Victorian era. Both the poets see disbelief, doubtfulness, alienation, confusion are the crisis of modern life which seems like a contagious disease. But the poets have a different perception of nature in their poetry. Mathew Arnold's representation of poetry seems to be a criticism to life where most of the poems had a melancholic and pessimistic tone echoing the sadness in the life of a modern man.

\section{Research objectives}

In general, this paper aims to identify the crisis or vulnerability of modern life portrayed by Mathew Arnold and Robert Frost, two poets who belong to two different eras. Besides, specific objectives are:

1. To analyze the similarities and dissimilarities of modern life depicted in the pre and mid-modern periods.

2. To examine different views in the representation of nature in relation to modern life.

3. To explore the pessimistic approach toward modern life.

4. To analyze the harshness of modern life mirrored in the work of two poets echoing today's society.

Copyright: (c) 2021 the Author(s). This article is an open access article distributed under the terms and conditions of the Creative Commons Attribution (CC-BY) 4.0 license (https://creativecommons.org/licenses/by/4.0/). Published by Al-Kindi Centre for Research and Development, London, United Kingdom. 


\title{
3. Research questions
}

1. What are the different philosophical approaches to modern life portrayed in the poetry of Frost and Arnold?

2. How are the elements of modern life reflected in the poetry of Arnold and Frost?

3. To what extent, people are delusional being detached from nature, and being attracted to materialistic life?

4. How are the works of the two poets still relevant?

\section{Findings of the study}

\subsection{Philosophical Approach of Arnold and Frost}

Critically examining the poetry of Arnold and Frost, it is visible that the poets have their unique philosophical approaches in their composition of poetry. Matthew Arnold is a poet of the Victorian age who represented social unrest, disbelief, material prosperity, and spiritual decline in his poetry. His poetry is often considered as a bridge between Wordsworthian romanticism and pessimistic modernism. As a modern poet, Arnold is being skeptical about modern life, and to him, poetry is "the criticism of life"(Arnold, 1888). Arnold's 'Dover Beach' is thought to be one of the finest poetic pieces of modernism that proceed from a peaceful, romantic landscape to a modern crisis of faith. Subsequently, he refers to both external and internal features that make the modern era ugly where he considered the dazzling world around him as a wasteland, sprawling in all its hideousness. To Arnold, the progress of society seems very superficial and a kind of self-glorifying that makes every person incomplete, unhappy, loitering in the darkness of ignorance, and striving for light and hope for surviving. In 'Dover Beach', Arnold (2006, p-1369) says:

"And we are here on darling plain swept with confused alarms of struggle and flight,

Where ignorant armies clash by nights (p-1369, lines 36-37)."

In addition, Arnold's "The Scholar Gipsy" has an ideal life of deep contemplation in the pursuit of truth. Whereas Victorians had a fickle life of enjoyment. While they have been caught in fatigue, doubts, uncertainties, and aimlessness, the scholar gipsy had a serene, resourceful mind. In this poem, Arnold makes a comparison between the free scholar gipsy, who rejected the Oxford degree to join the band of gypsies, with the doubtful Victorians who were chained with societal rules. He wanted to criticize the Victorian people who were selfish and indulged in self-entertainment, being detached from religion.

Frost is considered as a great upholder of modernity who is known for his portrayal of the disintegration of values, and disillusionment of modern man. His poem deals with characters who suffer from frustration, loneliness, helplessness, etc. which are known as modern evils and ills. His depiction of literary conventions and traditions of the past proves that his poetry is the epitome of modernity. The elements of his poetry are those of isolation, dilemma, self-centeredness of the modern man, the bored existence, etc. The poem "Home Burial" is based on a modernist theme that is known as self-centeredness. In this poem, the overwrought wife is merely a foil to her practical husband. Each of their views of life is very diametrically opposite. The wife, who is under the burden of grief over the death of her firstborn, cannot forget the fact that her husband was the one who dug the grave of their child.

In "An Old Man's Winter Night", the old man is lonely, completely alienated from the society, just like the tiredness of the farmer due to overwork in "Apple-Picking" and as a result of it his yielding to sleep:

\author{
"For I have too much \\ Of apple-picking: I am overtired \\ Of the great harvest I myself desired (p.38, lines-25-27)."
}

The Poem "The Road Not Taken" also deals with the dilemma of the modern mind. The poem depicts the bewilderment which exists in modern life.

\subsection{Treatment of Nature:}

Frost's poetry abounds in pastures and plains, mountains and rivers, woods and gardens, groves and bowers, fruits and flowers, and seeds and birds. However, his approach to nature and this natural phenomenon are different from the Romantics and are very realistic and modern in approach. His retreat to the countryside is not a romantic escape from the harsh, unpleasant realities of modern life. The rural world, the world of nature into which he withdraws, is not a world of dreams, a pleasant fanciful Arcadia, but harsher and more demanding than the urban world. Frost did not idealize or glorify the objects of nature. He saw them as things with which and on which man acts in the course of the daily work of gaining a livelihood. He rarely makes his lesson or his philosophy of nature as overt and obvious as Wordsworthian simplicity of style in his descriptions of Nature. In his poem "Birches" we find Frost's capacity for a minute and accurate picturization at their best and the opening lines of the poem are a characteristic example of the same. Here, he gives a concrete depiction of the "habits" of birches and the changes brought upon them by wind and ice storms. Young boys who swing on them. 
"When I see birches bend to left and right

Across the lines of straighter darker trees,

I like to think some boy's been swinging them.

But swinging doesn't bend them down to stay.

As ice' storm does. Often you must have seen them

Loaded with ice a sunny winter morning

After a rain. They click upon themselves

As the breeze rises and turned many-colored

As the stir cracks and crazes their enamel.

Soon the sun's warmth makes them shed crystal shells (p.47, lines 01-10)."

According to Frost, the world of nature is not a world of fantasy rather, it is tougher and rougher than the urban world. His poetry emphasizes the distinctive features of nature. His approach towards nature is scientific, rational, and objective. He presents both bright and bleak aspects of nature in his poem "Stopping by Woods in a Snowy Evening":

"Woods are lovely dark and deep

But I have promises to keep

And miles to go before I sleep

And miles to go before I sleep (p. 263, lines 13-16):"

In these lines, nature is represented as distractions as well as temptations in our life. Many people are losing their path in the journey of life then they give up hope and aspiration. Likewise, the speaker in this poem wants to stay in the amid of nature, rejecting his responsibilities and searching for peace away from the chaotic life. However, he comes to his senses and remembers his duties. That is why he convinces himself about returning to his daily life where he has "promises to keep."

He puts another example in his poem "After Apple-Picking" where the farmer gets bored with his routine and mundane job, and that's why he is not interested in apple picking. The farmer poet seems to be feeling tired with his busy life and fed up with the task of apple picking; he says:

"But I am done with apple-picking now (p.38, line 6)."

In his poem "Two Tramps in Mud Time", beneath the apparently beautiful calm there is lurking turmoil and storms.

"Be glad of water but don't forget.

The lurking frost in the earth beneath (p.298, lines 37-38)."

His realistic treatment of nature, employment of symbolic and metaphysical techniques, and the projection of the awareness of human problems of the modern society in his poetry are considered as the epitome of modernity.

Frost uses the pastoral technique only to evaluate and comment on the modern lifestyle. His pastoralism thus registers a protest against the disintegration of values in modern society. According to J.F. Lynen (2010), the use of the pastoral technique by Frost in his poems does not mean that the poet seeks an escape from the harsh realities of modern life. Similar to Frost, Arnold has used nature in his poetry. His descriptions are often picturesque and marked by striking similes. However, at the same time, he likes subdued colors, mist, and moonlight. Like Keats, Arnold's 'scholar gypsy' has escaped from the diseased world to the ideal world which is depicted in the following lines:

"Free from sick fatigue, the languid doubt,

Which much to have tried, in much been baffled, brings

O Life unlike to ours (p.1365, lines 164-166)!" 
Considering the conditions of the Victorian era, it can be sensed that it was a totally anti-pastoral age in its own nature as it is possible to see the lack of three unities. First of all, the industrial developments separated man from nature. This separation is not only metaphorical but also literal as the peasants had to move to the cities to work at the factories for earning money. Men's alienation from nature led to two other levels of alienation: First, they became alienated from themselves and then society. The lack of these unities is very much obvious in Arnold's poetry. Especially in "The Scholar Gipsy", the scholar gypsy was alienated from society as he did not feel that he belonged in the society.

\subsection{Self-Centeredness of Modern Man}

Selfishness is very much rooted in the heart of modern man as they live in the era of rationality where there is no place for emotion. The poem "Home Burial" by Robert Frost, is also based on a modern theme namely self-centeredness. Here the over agitated wife is a foil to the practical husband as they hold two opposite views of life. The wife, overburdened by the sorrow of her newborn child's death, can't forget that her husband not only dug the grave of their own child in their little graveyard but also buried him there himself. But to the husband, it seems a normal act that he should have dug the grave of his own son. He has come to accept the death of his son as an accident that can be submerged beneath the everyday existence of life. In order to make his wife accept the accident, the husband presents some arguments. He says,

"No, from the time when one is sick to death

One is alone and he dies more alone.

Friends make a pretense of following to the grave

But before one is in it, their mind is turned (p.87, lines 104-107)."

Thus, the husband speaks out the selfish nature of the modern men who even betray the dead. All human sympathy is gone and it has been replaced by selfishness. In this way, the poem is a modern domestic epic, which exposes some modern crises to our eyes. The title of this very poem symbolizes that the consequence of self-centeredness; the loss of relationship since it is the cause of turning their 'home' into a graveyard.

Frost's insightful yet tragic poem "Out, Out" - employs realistic imagery and personification of a buzz saw to depict how people must continue onward with their lives after the death of a loved one, while also hinting at the selfish nature of the human race, whom often time show concern only for themselves. Even though going on with life is a necessity, the speed at which the family and friends proceed to do so causes the reader to wonder what their motives are-necessity or selfishness. Frost personifies the buzz saw so that it seems to come alive with a will of its own. Frost gives a buzz saw an ominous air, a will of its own, when it "leaps out at the boy's hand" (p.151, line 15) as if to prove saws know what supper means". In this way, Frost shies away from the fact that the boy brings death upon himself by getting momentarily distracted from cutting the wood, accenting blame on an inanimate object. Along with this, the reader can also throw the blame on the parents for making the boy, "a child at heart" (line 20), take on adult responsibility to "do a man's work" (line 20) which results in the death of the boy. This materialistic behavior towards the child indicates their selfishness.

Throughout "Mending Wall", the poet indirectly raises the question of the possibility of change. The speaker is of the opinion that his neighbor's ideas are outdated. The speaker calls his neighbor an "old-stone savage armed"(line 41). He considers him a primitive man with a stone in his hands as if he is fighting a battle. On the contrary, the neighbor of the speaker is an old-fashioned man. The neighbor says only one sentence, "Good fences make good neighbor" (p.124, line 27) in the poem and repeats it. He speaks directly and in an unpretentious manner. The speaker emphasizes the unwillingness of his neighbor to think broadly. The only job that the neighbor is concerned about is the reconstruction of the wall to keep the distance between the speaker and himself, indicating the fact that he is more comfortable in staying all by himself without any kind of interference. The speaker highlights this side of the neighbor's character: his unwillingness to think broadly or deeply or to interrogate his own ideas. Instead of thinking things through for himself, the neighbor depends on "his father's saying[s]"(line 43) - that is, he relies on received wisdom. As a result, the neighbor seems to the speaker to be "like an old-stone savage armed" (p.124, line 40)

In "Dover Beach" the fourth and final stanza begins with a dramatic pledge by the lyrical self. He asks his love to be "true" (line 29), meaning faithful, to him. ("Ah, love, let us be true /To one another!" (p.1368, lines 29-30)). For the beautiful scenery that presents itself to them ("for the world, which seems/ To lie before us like a land of dreams, / So various, so beautiful, so new" (p.1368, lines.30-32)) is really not what it seems to be. Arnold felt that this shift in the Victorian era was too sudden and drastic, for them to be able to adjust. With the advances in technology, they felt like their roles and duties were being taken out from underneath them. As a result, the lover was scared that his beloved would be selfish just like others did not care for him any longer. That is why he persuades her to be truthful to him and not turn her into a person who only cares about herself or is too self-centered. Furthermore, he highlights the selfishness that existed in the world that resulted in wars. These ignorant soldiers seem to be in the dark as they do not know the consequences of this war and are only involved in them due to their selfish interest and desire for progression. The speaker was confused about modernity and doesn't know what to believe anymore, because everything in the 
world was based on selfish motives, where human emotions were totally rejected, creating a place for a more modern world where he felt helpless and lost. That is why the lover expressed his fear of losing his beloved to the verge of the modern selfish world. Arnold (2006, p-1368) argues:

"Ah, love! Let us be true to each other

To one another! for the world, which seems to lie before us

like a land of dreams, so various, so beautiful, so new,

Hath really neither joy, nor love, nor light,

nor certitude, nor peace, nor help for pain (p, 1368-69, lines 29-33)."

\subsection{Isolation and Alienation}

The poem that proved Frost as a modernist poet and modern in its approach was "Mending Wall". The poem is based on the theme of isolation that is very commonly visible in the life of modern people. Modern men have built boundaries and made themselves isolated from each other. Frost's metaphysical treatment of this physical and psychological isolation is also evidence of his modernity. In "Mending Wall", Frost juxtaposes the two opposite aspects of the theme of the poem and then leaves it to the reader to draw its conclusion. The necessity of fences is emphasized, implicitly criticizing the craze for pulling down fences and imposing brotherhood. The conservative farmer says:

"Good fences make good neighbor (p. 124, line 27)."

On the other hand, the modern radical farmer says:

"Something there is that doesn't love a wall (p.124, line 01)."

But the question remains unsolved. And it is up to the readers if they will keep the wall or pull it down.

One of the vivid features of modernism is the alienation that is acutely reflected in "Out, Out--". In this poem, people are related to each other but it lacks bonding or connection of the soul. They are so much isolated from each other that no one can feel the pain of others. When 'The boy' died, his family members did not react much. After the heartfelt accident, they took little time to go back to work. It indicates that in modern society, individuals are only concerned about their own wellbeing and survival. They are no longer concerned about the people related to them or the society.

\subsection{Pessimistic Approach}

Both Arnold and Frost share a pessimistic approach towards modern life through their poetry. Arnold considered the life of modern people as a 'strange disease' ( $p$-1366, lines 203) that is infectious. "The Scholar Gipsy" is a poem that narrates a story of an Oxford scholar who abandoned his oxford life and joined a band of gypsy, is a poem that explicitly highlights the tone of pessimism. In this poem, Arnold creates a comparison between the scholar Gipsy who lived 200 years ago, and the modern people. The poet was in despair as he found that the modern people are more selfish and detached from faith that is why he suggested the scholar gipsy go away from the modern people. As he is also feared that the scholar gipsy might be infected by this contagious disease that these people are suffering from.

Frost expressed his hopelessness in the poem "Birches" as it makes him remember his happy life in childhood contrary to the present unhappy state of mind due to the boredom of everyday life. As he says:

"And so I dream of going back to be.

It's when I'm weary of considerations,

And life is too much like a pathless wood

Where your face burns and tickles with the cobwebs

Broken across it, and one eye is weeping

From a twig's having lashed across it open (p.48, lines 41-46)."

Here birches make him nostalgic as he recalled his childhood days when he used to swing in it. The speaker wants to go back to his childhood days since he is overloaded with the responsibility of adult life. He expressed his frustration as he considered life as 'a pathless wood'. Escapism is prominent in the poem where he wants to leave the present world and want to go to heaven by swinging the birches but he cannot go back to his childhood and that makes him sad and pessimistic in his approach.

Delineation of nature is very vivid in Robert Frost's "Home Burial" but nature cannot heal the wound of modern life rather it becomes a source of despair instead of happiness. It is also the embodiment of pessimism as the very title of the poem suggests.

Page | 190 
Apparently, the word 'home' and 'burial' are contradictory in their meaning and the title suggests burial of home or relation and affection. The poem revolves around a couple who recently lost their child and going through a very rough time. Human relations are dried out in modern society as they cannot hold affection for each other. As the wife utters:

'You—oh, you think the talk is all. I must go-

Somewhere out of this house. How can I make you (p.88, 116-117) -'

The wife's departure from home at the end of the poem suggests the ending of a relationship or affection between them. It ends in a pessimistic tone since there is no hope of mending the relationship.

In "Mending Wall", the neighbor is considered as primitive who believes in mending the wall. If they mend the wall regularly then there is no hope of erasing the distance between them. In this way, the poem states its pessimistic tone.

In "Out, Out", lack of emotion among family members is evident here as they act normal in the time of untimely death of 'a boy'. The effect of industrialization is acute here as 'the boy' is sent to do man's work. It makes people emotionless. The poetry ends in a note of disappointment as it shows the cold reactions of the family members to the death of 'the boy'.

\subsection{Crisis of Modern life Existing in Today's World:}

The crisis of modern life is still evident in today's society. People are getting emotionless to meet the standard way of life day by day. They have no free time to spend with family and friends that is creating a bad effect on their mindset and making them alienated from their near and dear ones. Modern people became emotionless, totally blind to others' suffering and miseries, and self-centered. Just like the poem "Out, Out", where the family members were not upset about the death of a young member of the family and returned to their normal life, in this corona pandemic, people are only concerned about themselves not worried about other's lives. Their sympathy for the dead people is only restricted to a few moments' sighing and being relieved that they are not the ones listed among the dead. This reveals how modern men have turned heartless and selfish. The famous quotation of Jean-Jacques Rousseau, "Man is born free, but everywhere is in chains" truly defines the state of modern man. Today people think they have liberty but their freedom is restricted to social norms and rules. In the "Scholar Gypsy" Arnold made a comparison between the gypsy who was a free spirit and rejected his Oxford knowledge to gain practical knowledge while the modern man suffering from the disease of modernism who weren't brave enough to challenge society and its knowledge. People of today's world do not challenge the rules that society imposes on them rather they fear being rejected going against societal practices and tradition. Nowadays, we can see that people enjoy their privacy and want to maintain a barrier with others. The poem "Mending Wall" represents this topic of individualism and isolation. The neighbor wants to mend the wall with a view to keeping a distance from the speaker. Similarly, today we are not very comfortable in maintaining a good relationship with our neighbors. We want to restrict our relation to formality. We are more comfortable in being social in "social media" than having a good relation personally. People have become unsocial and want their privacy to be maintained.

\section{Conclusion}

The paper aims to identify the crisis and vulnerability of modern life depicted in Mathew Arnold and Robert Frost's poetry where the focus is to analyze the similarities and dissimilarities in their philosophy, representation of nature, and pessimistic approach towards modern life. In addition, this paper also explored the connection between the harshness of modern life and today's society. Both the poets belong to two different eras assume similar realizations about the crisis of modern life. They are equally skeptical and pessimistic about modern advancement and modernity but retain different philosophical approaches in their poetry and treatment of nature. They are very much critical about the life of modern man. The crisis, instability, and vulnerability of modern man have been highlighted whenever they compose any poetic pieces. Even nature took a diverse shape as they treat it not to provide solace to the soul's wound but to represent alienation and other insecurities of mankind. Evidence of pessimism has also been found in their writings. In addition, both the poets are thoughtful about the misery and crisis which existed in modern life as well as possess strikingly common features in their writings. This comparative study will guide the future researcher who will conduct research on comparative literature. Besides, this paper will be an addition to the existing research on the Victorian and Modern periods. Furthermore, it showed how these modern crises are still relevant in the present world. It will be a source of inspiration for those who want to conduct research on contemporary society. Due to the lack of time and resources, there might be some gaps in the research findings. Besides, there was no financial aid for conducting this research. Owing to these limitations it could not be conducted on a large scale. 


\section{References}

[1] Ali, M. (2012), Modern Elements in Matthew Arnold, https://malinotes.blogspot.com/2012/06/modern-elements-in-matthew-arnold.html.

[2] Al-janabi, M.M.S., (2017) Modern Mutations: Alienation in the Poetry of Robert Frost, https://www.researchgate.net/publication/329196302/.

[3] Almiqdady, M. Z., Abu-Melhim, A. R. H.,\& Al-Sobh, M. A. (2015), The Concept of Nature in the Poetry of William Wordsworth and Robert Frost: A Comparative Study. Arab World English Journal (AWEJ) Special Issue on Literature No.3, 153-166, http://dx.doi.org/10.2139/ssrn.2843966

[4] Arnold, M. (1880), Study of Poetry, The English Poets, London, Macmillan and Co Critical Appreciation of Robert Frost's Poem Birches. (2017, August 16), AD's English Literature Notes and Guides. https://ardhendude.blogspot.com/2017/08/critical-appreciation-of-robert-frosts.html.

[5] Greenblatt, S., Abrams, M. H. (1888), The Norton Anthology of English Literature, Eighth Edition, Volume 2, W.W. NORTON \& COMPANY, London

[6] Hudson, W.H. (1993) An Outline History of English Literature. London: G. Bell \& Sons, Ltd.

[7] Kaushik, M., (2016), Robert Frost and Modernity in Poetry, Ashvamegh, https://ashvamegh.net/.

[8] Lang, C. Y. (1996), The Letters of Matthew Arnold. Charlottesville and London: The University Press of Virginia,. Volume 3. 347.

[9] Meenakshi, T., (2016), Modernism and its application in Robert Frost's Poems, After Apple-Picking, The Road not taken and Mending Wall, Int. J. Eng. Lang. Lit \&Trans. Studies Vol.3.Issue. 2.2016(Apr-Jun), http://www.ijelr.in/.

[10] Rahayu, A. C. (2020). Three Critical Approaches in Literary Criticism: An Example Analysis on Matthew Arnold's Dover Beach, Anaphora: Journal of Language, Literary, and Cultural Studies Page 65-73, Volume 2 No. 2 December 2019.

[11] Romy, (2018), Robert Frost as a Modern Poet, International Journal of Creative Research Thoughts (IJCRT) 1801367, Volume 6, Issue 1, http://www.ijcrt.org/.

[12] Vandana V., (2019), Mathew Arnold's The Scholar Gipsy: A Pastoral Elegy, International Research Journal of Commerce Arts and Sciencehttp://www.casirj.com. 